UDK 343.8(497.115)

613.86-053.6(497.115)

doi: $10.5937 /$ bastina33030

Pregledni rad

\author{
Gordana S. JOVANOVIC \\ Nikola Z. PAVLOVIC** \\ Kosovo and Metohija Academy of Applied Studies
}

\title{
HEALTHY POPULATION AS A STRATEGIC RESOURCE IN THE ECONOMY OF KOSOVO AND METOHIJA
}

\begin{abstract}
One of the central issues of the modern age is related to the prevention of excessive use of narcotics, but also the Internet and electronic devices in the everyday life of young people. This leads them to loneliness, distance from society, family, people, nature... In order to prevent these problems of the modern age, it is necessary to continuously look for solutions. Some of them are related to youth engagement programs through sports activities outside the regular curriculum. The aim of this paper is to alert the public, especially the intellectual ones, to the necessity of including this type of extracurricular activities in the development of young people's personalities. The results of the research provide an overview of sports activities that should first be introduced into the plan of extracurricular activities, and which will introduce young people to a healthy growing up, and contribute to their physical and intellectual progress. The paper seeks to point once again to the population as a significant driving force in the development of economies, sports as a significant export branch, a powerful weapon against addiction, and a means of combating crime.
\end{abstract}

Key words: youth, population, economic resources, extracurricular activities, sports.

\section{INTRODUCTION}

The situation with COVID-19, which shook the world economy over the year, confirmed once again that a healthy and intellectually strong population is a generator of economic growth of national economies. Recognizing this indisputable fact, national governments must pursue clearly defined demographic policies. Special attention should be paid to young people who are just entering maturity, and are facing great life temptations and challenges of youth.

* Professor of Applied Studies, gordana.jovanovic@akademijakm.edu.rs

** Professor of Applied Studies, nikola.pavlovic@akademijakm.edu.rs 
Globalization has affected the whole world, and the lives of everyone. Although many are of the opinion that they are isolated from its influence, that children can be protected, unfortunately, life assures that this is not the case. The vices that enter their lives through a small door are never more accessible to young people. Innocent "playing tickets", drinking low-alcohol drinks, or just smoking a cigarette, are just a ticket into the world of adults and creating an addiction to the strongest vices.

However, these are not the only challenges for young people, perhaps the biggest addiction, which begins in early puberty, occurs through the Internet and all that it provides. Too much information constantly available to young people " $24 / 7$ " disturbs their realistic perception of life and creates an unrealistic picture of true values but also life goals and ways to achieve them. Such a perception of "values" in young people causes negative psychological states. If we add to that games that are mostly based on "shooting", a sedentary lifestyle, then it is not surprising that young people are encouraged to aggression, which is replaced by a high level of displeasure.

The goal of the research is to provide answers to today's challenges, so as to offer sports and sports activities as the best solution that brings numerous benefits. The paper seeks to explore which sports activities within the extracurricular engagement of children are the most interesting for children and parents. The research results point out the most interesting sports. Guided by the research goal, the paper uses the following hypotheses: Hypothesis I, Extracurricular activities animate children and improve personal satisfaction, providing a higher quality of life, better and more meaningful use of free time, thus reducing health care expenditures. II Sports activities, on the other hand, create a realistic base for the growth of basic economic quantities.

\section{LITERATURE REVIEW}

Drug use and addiction to this opiate addiction have accompanied the human race since ancient times. Numerous pieces of evidence testify to that. The ancient Sumerians, are still around 5000 BC (Zdravi grad Poreč 2015), took opium about which there are written traces. Addiction is a global problem today. There is a huge availability of numerous opiates, legal but also illegal. It is in human nature to succumb easily to anything that increases pleasure and mood, often ignoring the dangers that may arise from it. Modern time brings with it a modern way of pleasure. The development of Western civilization creates a new way of life, fun, new pleasures, primacy is on material things, which require superiority in the rhythmic life that seeks to achieve them (Zdravi grad Poreč 2015). Hedonism is no doubt, an imperative of today, the ultimate goal 
is pleasure, no matter how much it costs. If we look at all of the above, there is no doubt that adolescents will succumb to pressures and reach for some opiate during their growth and development. The National Commission for the Prevention of Addiction 2005 (5), clearly indicates the existence of processes in the emergence of addiction to psychoactive substances and the importance of social processes and changes in social customs, which accompany the transition of our society. Sakoman (Sakoman, quoted Kovačić (2013: 18) believes that the protection and improvement of health within the primary prevention of addiction contribute to a better and longer life of each individual, and drug use is considered today as the most common and influential cause of physical and mental health disorders, behavioral disorders in humans, which also leads to an increase in crime. Thus there is a need to strengthen and develop healthy lifestyles of young people in order to reduce the impact of risk factors and external pressures. Based on numerous research studies, Dimitrijević (2007) regards school programs that include young people prior to the establishment of subordinate forms of behavior as prevention of drug addiction and a framework for the promotion and preservation of the health of young people. Since risky behaviour does not exist as an isolated, individual form, but most often, there is a connection between several forms; programs for healthy lifestyles of young people should start from kindergarten continuing through primary to secondary schools.

Just as opiate consumption creates a number of negative consequences for consumers, so the new scourge of the modern age, the Internet and social networks, cause new psychological states in young people, but also in the elderly. Social networks provide an entrance into an "imaginary world" that may be fun and relaxing, but at the same time it represents an escape from reality and facing one's own life (Prpić2016). Stanimirović S. 2019 starts from the fact that social networks, which were originally created to make people's lives easier and encourage communication, have now grown into their opposite. People try to present themselves in the best possible light. However, when young girls review over 100 posts of girls who are perfectly made up, dressed, with magnificent natural and built objects in the background of the photos, they will probably feel bad. This is how a complex of lower value is created, which is not uncommon nowadays. This leads us to the conclusion that social networks have a high level of risk for the development of deviant behavior. Nikolčić 2020, points out that addiction to social networks looks almost like any other addiction disorder caused by illicit substances, including mood swings, cognitive and emotional preoccupations, greater use of social media over time, withdrawal symptoms (causing unpleasant physical and emotional symptoms in conditions of limited or discontinued use of social media), conflict and relapse (after a period of abstinence, "addicts" quickly return to excessive use of social networks). 
Unfortunately, "going to social networks" in addition to the above, causes a number of other negative connotations: headaches, neck pain, poor concentration, laziness, unconscious consumption of food and drink, loss of useful time, identity theft, creating a "poor" image of oneself because of the opinion that others lead a more fun life"

If we look from the angle of the organism, all addictions, regardless of the matter (drugs, alcohol, gambling, video games, social networks) cause the same brain changes. Receptors in the brain react in the same way, regardless of the stimuli in question (Zdravi grad Poreč 2015). Addiction causes anything that can briefly evoke a mood. However, any addiction diminishes the degree of freedom and personal control of the addict. Stimulus addicts, in the end, have much bigger problems than the ones they wanted to avoid.

Stimulants can be used by people of all ages, but the most at-risk group are adolescents. The motives of young people to reach stimuli, especially drugs, are more numerous and different (UNICEF u Srbiji i Crnoj Gori2004):

- curiosity,

- inferiority and low level of self-esteem,

- lack of parental attention and love,

- poor property card

- striving to present oneself as an important person, etc.

In young people, the use of stimulants causes withdrawal. They spend most of their free time alone, and only a little in the company of friends and family. They become insecure, listless, unhappy. These psychological problems of young people, later have their repercussion on indecision in choosing a school / faculty, poor information about the labor market, insufficient knowledge of their own abilities, interests, competencies and values.

Suppression of addiction is the dominant problem of today, in the following, the authors point out the best ways to solve the disease of addiction.

\subsection{HOW TO PREVENT ADDICTION DISEASES}

As we have already stated, young people today face numerous challenges. The responsibility for their maturation and development into innocent personalities is for the most part the responsibility of parents, i.e. the family, but also of the social community, especially educational institutions.

The family is the basic cell of society, and as such it is a pillar of strong states, not young people. Family support, love they receive from all members, monitoring, upbringing, respect for children as equals, attention and time for each individual child, listening to children, their feelings, support in each segment, meeting their friends, are the essence of parental support for growing up 
(Zdravi grad Poreč 2015). Soković G. 2016, summarized empirical research with regard parental influence on children's behavior in sports and confirmed their undeniable and huge influence. Parents are the ones who are crucial in deciding on the choice of their children's first sports activities. Anderson and Wold (Mileva Radović, Ljubica Bačanac, Ana Vesković) (1992) find that sports engagement of parents is not itself a sufficient incentive for their children to get involved in sports. On the contrary, the support of children by parents and other members of the immediate and extended family is much more important from the role of a sports prototype. It is wrong for parents to have a tolerant attitude even for the smallest vices, because the path to any addiction to hard drugs is paved by experimenting with nicotine and alcohol. The best examples for children are their own, i.e. examples of parents. When there is no smoking in the family, or drinking in a controlled way, children judge vices in the right way (Zdravi grad Poreč 2015).

Respect for the law - The law clearly defined the sale of alcohol to minors, so there is a ban on selling to persons under 18 years of age. The law is binding on everyone, all citizens, parents are obliged to respect the law and make sure that all members of the community abide by it, in order to protect their own and other children. In order for the law to be fully complied with, the work of the repressive police body is also important (Zdravi grad Poreč 2015).

Prevention programs - Guided by our own, but the common sense of the authors whose views we have stated, we believe that national policies of certain countries must be involved in the process of preventing behavioral problems. The task of experts in this field is to acquaint "key people" with potential problems, while emphasizing the importance of prevention that could prevent these problems. Guided by the old "better to prevent than to cure", it is necessary to "employ" young people and occupy their attention completely. The best form of such support is the education system. Here there is the most space for organizing extracurricular activities in which young people should be involved. Playing sports through physical education classes is not enough, so children should be encouraged to use their free time in physical activities that are not part of regular classes. Sports activities are the best way to engage children and provide numerous benefits, such as (UNICEF u Srbiji i Crnoj Gori 2004):

- through sports, children and youth are trained to think critically while looking for solutions to a problem;

- friendships spread,

- symptoms of stress and depression are reduced,

- young people learn fair competition,

- the importance of teamwork is recognized,

- self-discipline, 
- respect for competition;

- creates leaders, future leaders who will possess problem-solving skills, creates responsible young people, creates a responsible nation. Through sports, young people learn not to give up;

- sports activities are a great place to promote a healthy lifestyle. Sport is a powerful weapon against vices such as drugs, alcohol, tobacco, fast food, gambling, crime;

- a healthy and educated nation is a powerful mechanism for the growth and development of national economies.

In order for high schools to build their own image, to be better than the better ones, they must constantly innovate, in the areas of the teaching process, professional development of staff, designing new profiles and occupations. Schools, too, must pay a lot of attention to sports and other non-teaching activities, in order to make better use of students' free time. There must be various types of youth animation in schools: engaging young people in professional development in the field for which they are studying; development of creative ideas and preparation for various types of competitions. However, there is still enough free time of young people to be used in the right way. Sports and sports activities appear as key activities that can animate young people and distract them from the "street".

\section{MATERIALS AND METHODS}

There are many optional sports that can be of interest to children in extracurricular activities. The research of the authors was conducted in order to provide the right choices, and full engagement of school resources, but also society, which must be a systematic and financial support to this form of prevention. The research was conducted for the needs of the secondary school "Nikola Tesla" within the second phase of the development of the T2P case study Engaging children through sports and other activities in order to make better use of their working time. The research was conducted in the period from 10 March to 20 March 2020 on a sample of 60 respondents aged 15-45, by survey method. The largest number of respondents included students of the mentioned school aged 15-19, 43 of them (71.7\%), while the remaining number, 17 of them $(28.3 \%)$ were aged $19-45$. The survey also included a number of parents, 11 of them or $18.33 \%$.

The questionnaire has been structured so that it optionally offered 10 sports, which in the opinion of proven experts in this field are the best choice for children's psychophysical health, their physical and intellectual development, and at the same time very interesting for children to perform. Respondents had 
to choose five of the ten sports offered. They could choose: outdoor activities, judo, karate, modern dances, ballet, gymnastics, fitness, artificial rock, endurance exercises and darts. Please note, not all sports covered by the survey are randomly selected, each of them develops traits that are neglected by the modern way of life.

Respondents had the space to comment on this idea and give their own judgment.

The collected quantitative statistical data were analyzed using descriptive statistics in order calculate, present and describe the basic characteristics of statistical series obtained by research activities.

\section{RESULTS AND DISCUSSIONS}

The results of the conducted research are presented in Table 1 . The overview of the five most attractive sports based on the opinion the respondents is presented in the mentioned table, while the sports for which the smallest number of respondents opted are classified under the others.

Table 1. The most attractive sports for extracurricular activities

\begin{tabular}{clc}
\hline $\begin{array}{c}\text { Serial } \\
\text { number }\end{array}$ & \multicolumn{1}{c}{ Types of sports } & $\begin{array}{c}\text { Percentage share of sports in relation } \\
\text { to other surveyed sports }\end{array}$ \\
\hline 1. & outdoor activities & $27 \%$ \\
\hline 2. & judo & $19 \%$ \\
\hline 3. & modern dances & $19 \%$ \\
\hline 4. & fitness & $15 \%$ \\
\hline 5. & artificial rock & $12 \%$ \\
\hline 6. & other & $8 \%$ \\
\hline
\end{tabular}

The research, which included young people, but also their parents, showed that the largest number of respondents, $27 \%$ of them, believe that young people should be offered outdoor activities, such as hiking, camping, camping, nature trips. This figure is not surprising, because young people lead a sedentary lifestyle, and the most attractive way out of the room is through socializing with peers in nature. In this way, young people move away from everyday life and get to know themselves better, but also each other. Friendships gained in this way are more sincere and lasting than those through social networks.

Judo as a form of sports activity, and a popular martial art, in addition to other sports of this type provides prevention of violence among young people, 
contributes to the application of ethical principles in sports, while the opponent is highly respected. Namely, the goal is to defeat the opponent so that he remains unharmed. $19 \%$ of respondents believe that judo should be introduced in extracurricular activities of young people (Radenović, Mijatov 2019).

Modern dance such as Salsa, Bacata, Kizomba, Tango, Belly Dance or Ballet (19\% of respondents voted for this form of extracurricular activities). It is generally known that dance has a very positive effect on the body, spirit and mind. First of all, it ensures that the body is better physically built, better coordination of movements, as well as more correct posture, while intellectually dancing increases the ability to remember, encourages creativity and the desire to master something new.

Fitness is a very attractive sports activity. Exercise is accompanied by music, through imaginary choreographies through which all the muscles in the body are engaged, they develop motor, fitness and coordination abilities in girls, and it also contributes to the harmonious development of the whole body.

An artificial rock, which would be placed along the wall, would provide students with the basic elements of free climbing. It is an extremely demanding physical activity, where students have to overcome rocks without aids, only with the strength of their body, while at the same time having a correct perception of space and their own possibilities.

The mentioned initiative for the introduction of sports in children's extracurricular activities is justified and supported by the public as shown in the comments of the respondents, who justify such moves only with words of praise.

In addition to the listed ways of disease prevention of the modern age, it is necessary to provide organized support to young people and their families through various counseling, education and recommendations. The teaching staff should be included in the process, which through the education system is trained for early recognition of young people with addiction.

\subsection{OTHER BENEFITS OF SPORTS}

In order to economically justify the motive for introducing extracurricular activities in school curricula and to provide financial support from competent authorities, the intention of the authors was to present other benefits of sports.

Sport as an integral part of the educational system starts from the first year of school and last until going to study. In this way, a large number of countries offer a considerable number of years of sports education to some individuals. Hence, it is not surprising that sport is also treated as an economic activity. Sports in the field of sports, all countries pay great attention, however, Denmark, 
Estonia and Lithuania are the countries leading in this field. They have a very high share of sports in the related gross value added of sports.

Sustainable economic development and sustainable economic policy must be based on high growth rates, which result in relatively high gross domestic product and relatively high GDP per capita. The question that arises from that logically arises, and it refers to whether sport and to what extent can contribute to sustainable development. Back in 1946, Rottenberg pointed out that there are actually no significant differences between sports and other activities: they participate equally in income, the level of earnings is huge, distribution is provided with maximum amounts of salaries and market franchises, etc. The economic impact of sporting events can be defined as the net change in the economy caused by a sporting event (Sloane 2006)

In recent decades, sport has transformed as an economic sector. There was an interaction between business and sports. Its multiplied effect on the achieved level of income is visible through repercussion on other sectors of the economy. Organization of sports events, rights of their transmission, various forms of sponsorship of sports events, public-private cooperation in building sports infrastructure, results in large investments in sports, which transcends the sports scene. The economic effects are especially visible in the field of tourist services. With the organization of sports events, the number of realized overnight stays, the utilization of catering and transport capacities, the tour of cultural and historical facilities and tourist attractions is growing.

Sport, as a continuum of motor and physical activity, is linked to a wide range of policies, products and services concerning different value chains and influences on them. Overall, the sports sector accounts for $2 \%$ of the EU's global GDP, while the total employment generated by sports activities is 7.3 million, corresponding to $3.5 \%$ of total employment in the EU. Despite these impressive figures, the economic performance of sports industries is often underestimated. Sport is a lever for innovation, industrial competitiveness and employment.

Sport is an activity that opens wide doors for employment, so the data for the EU as a whole is $2.12 \%$, which is a total of 4.46 million employees. Germany has the largest number of sports jobs, somewhere around 1.15 million or about $27 \%$ of all sports-related jobs in the EU. Until recently, the United Kingdom has about 610,000 EU members, while France has more than 410,000 jobs in sports. It should be added that with the development of sports, the health care system is growing, which also opens up space for employment (source: www.gbe-bund.de).

Investing in sports is not an expense. Investing in sports is an investment. And it is certainly the best investment to invest in young people. 
Table 2: Contribution of GDP in the top 10 sports sectors

\begin{tabular}{|c|c|c|c|c|}
\hline Rang & CPA & Goods and services & $\begin{array}{l}\text { GDP in } \\
\text { mil. euros }\end{array}$ & $\begin{array}{l}\text { Share of } \\
\text { total GDP }\end{array}$ \\
\hline 1. & $\mathrm{P}$ & Sports services & 51,237 & $0.39 \%$ \\
\hline 2. & R93_1 & Sports services & 43,075 & $0.33 \%$ \\
\hline 3. & $\mathrm{O}$ & $\begin{array}{l}\text { Public administration and defense services; } \\
\text { compulsory social security services }\end{array}$ & 32,244 & $0.24 \%$ \\
\hline 4. & I & Accommodation and catering services & 23,217 & $0.18 \%$ \\
\hline 5. & G47 & $\begin{array}{l}\text { Retail trade services, except motor vehicles } \\
\text { and motorcycles }\end{array}$ & 19,868 & $0.15 \%$ \\
\hline 6. & G46 & $\begin{array}{l}\text { Wholesale trade services except of motor } \\
\text { vehicles and motorcycles }\end{array}$ & 16,352 & $0.12 \%$ \\
\hline 7. & $\mathrm{~F}$ & Buildings and construction works & 9,932 & $0.08 \%$ \\
\hline 8. & R90-92 & $\begin{array}{l}\text { Creative, artistic, entertainment, library, } \\
\text { archive, museum and other cultural services; } \\
\text { gambling and betting services }\end{array}$ & 9,493 & $0.07 \%$ \\
\hline 9. & Q86 & Health services & 8,230 & $0,06 \%$ \\
\hline 10. & H49 & $\begin{array}{l}\text { Land transport and transport services via } \\
\text { pipelines }\end{array}$ & 6,645 & $0.05 \%$ \\
\hline
\end{tabular}

1. Source: SpEA, 2018, cited in Miličević, E,(2019), Ekonomski aspekti tržišta sporta i njihova važnost u nacionalnim ekonomijama-primjer EU, Sveučilište Jurja Dobrile u Puli Fakultet ekonomije i turizma: 15 [online]. Available at: https://repozitorij.unipu.hr/islandora/object/ unipu\%3A3295/datastream/PDF/view_(Accessed: 21st July 2020)

Table 2 shows the top 10 sports sectors (out of 42) in terms of GDP. "CPA" is a categorization of goods and services used in the system of national accounts (SNA) and are shown as an abbreviation for the middle column. The GDP of a particular category is shown in millions of Euros, as well as the share of total EU GDP.

From the table we see that 51 billion Euros, or $0.39 \%$ of EU GDP, are brought by sports education services, which is almost the same as all forestry and wood products, except furniture ( 55 billion Euros). "Sports Services", the second largest sector, is the only largest sector in sports in the SNA. It includes work on sports facilities, sports clubs, fitness and other sports services (e.g. sports promotion or athletes). Generating more than 43 billion GDP or $0.33 \%$ of total EU GDP, it is clearly exceeding. "Human health services" are twofold, including the treatment of sports injuries and sports as a treatment (SpEA, 2018).

Sport can be treated as a significant export branch. There are numerous examples of state revenues based on the employment of athletes abroad. For example, Iceland and Montenegro are the countries with the largest number of 
international footballers in relation to the number of inhabitants. ${ }^{1}$ Montenegro is especially interesting, which according to the representative and club competition for all ages, at the bottom of the scale in terms of success, but is therefore in the second segment at the very top of the world, namely, according to the report of "CIES", a Swiss observatory that analyzes and According to football statistics, Montenegro ranks second in the world in the number of top football players in relation to the number of inhabitants. All the others are far below, with the proviso that Montenegro is the only country with less than a million inhabitants that has over 100 players abroad.

Unfortunately, football players from Montenegro usually leave without much compensation, because they start in a weak league, what's more, they leave as teenagers, and they only mature when they try out in a stronger rank. Based on that, we conclude that football is the largest export branch of Montenegro, which, paradoxically, does not bring too much money, which is not in line with the image of this "most important sideline" in the world.

\section{CONCLUSION}

The intention of this research was to draw attention to some of the basic challenges that young people constantly face today. The paper identifies and explains ways to include children in sports and other activities. Another dimension of sport is given, as a means to be applied in order to prevent the challenges of the modern age that young people are constantly facing. Analysis of the literature and attitudes of experts in the field of medicine confirmed the initial hypothesis. Thus investing in sports through extracurricular activities "produces" a healthy and energetic population, which has a predisposition to education and professional development. Extracurricular activities animate children and improve personal pleasures (selected sports contribute to the development of harmonious body figures) providing a higher quality of life (direct contact and socializing with peers in dance, in nature, provide emotional development, and better mood due to closeness and direct contacts) and more purposeful use of free time. As sports activities fully include motor and bodily functions, there is no doubt that sports and sports activities improve health and contribute to the adoption of healthy living habits.

The paper points out the importance of sports through economic parameters. It has been observed that sport and all the industry it entails (inclusive or sports tourism, technology, health, trade, construction and infrastructure) directly and indirectly contribute to the creation of added value. Based on this, we conclude that sport is not a marginal activity, but a priority area in terms

1 Icelanders have an international football player per 5,200 inhabitants and Montenegro per 6,000. 
of investment. In this way, the second hypothesis was confirmed that sports activities create a realistic basis for the growth of basic economic variables.

Sport in the modern economy brings significant advantages for local and regional authorities in terms of: the sectors affected by sport, competitiveness, employment. As sport increasingly serves as a means to achieve social and economic goals, the sports sector needs to be further improved and made more productive and effective, not only in terms of planned goals but also in terms of sport as an essential and strategic goal itself.

\section{REFERENCES}

Joković-Miletić-Rajković 2019: Jovana Joković-Jovana Miletić-Tatjana Rajković. „Uloga vančasovnih nastavnih aktivnosti na suzbijanju prevencije siptomatičnog ponašanjau osnovnim i srednjim školama“, Aktuelnosti u teoriji i praksi sporta, fizičkog vaspitanja i rekreacije. Zbornik radova. Ur. Darko Mitrović, Vladimir Miletić, Tatjana Rajkovic. Beograd: Fakultet sporta i fizičkog vaspitanja Univerziteta u Beogradu, 90-97.

Dimitrijević 2007: Bojana Dimitrijević. Narkomanija kod mladih. <https: / www.stetoskop.info/ zdravlje-mladih/narkomanija-kod-mladih $\geq[03.12 .2020]$.

Kovačić 2013: Nikola Kovačić. Uključi kreativnost isključi drogu - priručnik za rad.<(PDF) Uključi kreativnost isključi drogu - priručnik za rad | Nikola Kovacic - Academia.edu> [03.12.2020.]

Mandarić, Labudović 2019: Sanja Mandarinić, Dragana Labudović. „Aktuelni trendovi svetske federacije sportskog plesa", Aktuelnosti u teoriji i praksi sporta, fizičkog vaspitanja i rekreacije. Zbornik radova. Ur. Darko Mitrović, Vladimir Miletić, Tatjana Rajković. Beograd: Fakultet sporta i fizičkog vaspitanja Univerziteta u Beogradu, 128-133

Miličević 2019: Ena Miličević. Ekonomski aspekti tržišta sporta i njihova važnost u nacionalnim ekonomijama-primjer EU, Pula: Sveučilište Jurja Dobrile u Puli Fakultet ekonomije i turizma <https://repozitorij.unipu.hr/islandora/object/unipu\%3A3295/datastream/ PDF/view>. [21.07.2020.].

Mitrović 2019: „Primena nacionalne strategije Republike Srbije na suzbijanju nasilja i nedoličnog ponašanja na sportskim borilištima“, "Aktuelnosti u teoriji i praksi sporta, fizičkog vaspitanja i rekreacije. Zbornik radova. Ur. Darko Mitrović, Vladimir Miletić, Tatjana Rajković. Beograd: Fakultet sporta i fizičkog vaspitanja Univerziteta u Beogradu, 15-23

Nikolčić 2020: Tamara Nikolčić. Zavisnost od društvenih mreža, kako utiče na mozak <http:// www.radiocool.rs/2020/02/zavisnost-od-drustvenih-mreza-kako-utice-na-mozak/>. [13.12.2020.].

Prpić 2016: Tomislav Prpić. Izazovi i mogućnosti prevencije prekomjernog korištenja društvenih

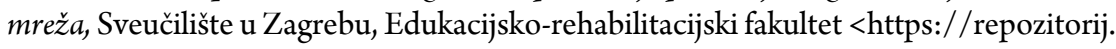
erf.unizg.hr/islandora/object/erf\%3A161/datastream/PDF/view> [23.07.2020.]

Radenović, Mijatov 2019: SandraRadenović, Nikola Mijatov. „Mogućnost implementacije džudoa u skolski sport kao mera prevencije nasilja u skolama"Aktuelnosti u teoriji i praksi sporta, fizičkog vaspitanja i rekreacije. Zbornik radova. Ur. Darko Mitrović, Vladimir Miletić, Tatjana Rajković. Beograd: Fakultet sporta i fizičkog vaspitanja Univerziteta u Beogradu,59-63 
Radović, Bačanac, Vesković2005: Mileva Radović, Ljubica Bačanac, Ana Vesković. Uloga porodice u sportskoj aktivnosti dece. Belgrade, Serbia July 13-16. 10th Annual Congress European College of Sport Science, 9-16

Stanimirović 2019: StrahinjaStanimirović. Koliko društvene mreže stvaraju zavisnost <https:// youthvibes.rs/koliko-drustvene-mreze-stvaraju-zavisnost>. [12.02.2020.].

Soković 2015: Goran Soković. „Uloga porodice u skolskom sportu“, Sport i zdravlje, X2, 94-100. Živaljević 2020: Slaviša Živaljević. Vjerovali ili ne - fudbal je najveća izvozna grana Crne Gore, a donosi malo novca, Vijesti online, 24 April,<https://www.vijesti.me/amp/431755/ vjerovali-ili-ne-fudbal-je-najveca-izvozna-grana-crne-gore-a-donosi-malo-novca $>$. [26.08.2020.].

Zdravi grad Poreč 2015: Ovisnosti-problem i izazov modernog doba< https://www.zdravigrad-porec.hr/o-nama/sto-je-zdravi-grad/>. [26.08.2020.].

UNICEF u Srbiji i Crnoj Gori 2004: Sport, rekreacija i igra <http://www.unicef.rs/files/ SPORT,\%20REKREACIJA\%20I\%20IGRA.pdf>.[12.01.2021.].

United Nations Office for Drug Control and Crime Prevention 2002: SPORT using sport for drug abuse prevention<https://www.unodc.org/pdf/youthnet/handbook_sport_ english.pdf $>$.[12.01.2021.]. 


\section{ГорАана С. ЈОВАНОВИТ}

Никола 3. ПАВАОВИЋ

\section{ЗАРАВО СТАНОВНИШТВО СТРАТЕШКИ РЕСУРС КОСОВА И МЕТОХИЈЕ}

\section{РеЗиме}

ЈеАно оА централних питања модерног доба веже се за превенцију прекомерне употребе опојних срестава, али и интернета и електронских уређаја у свакодневном животу младих. То их одвлачи у самоћу, Аистанцираност оА Аруштва, породице, ьуди, природе... Како би предупредили ове проблеме савременог доба неопходно је континуирано тражити решења. Нека оА њих везана су за програме ангажовања младих кроз спортске активности изван реАовног плана наставе. Циь рада усмерен је на алармирање јавности, посебно интелектуанна на неопходност укьучивања овог виАа ваннаставних активности у развој мичности младих. Резултати истраживања Аају преглеА спортских активности које најпре треба Аа истраже у пиану ненаставних активности, а које ће младе увести у јеАно зАраво одрастање, и допринети њиховом физичком и интелектуанном напретку. РаА настоји да још јеАном укаже на становништво као значајну покретачку снагу развоја економија, спорт као значајну извозну грану, моћно оружје против болести зависности и среАство за сузбијање криминала.

Кьучне речи: мкаАи, становништво, економски ресурси, ваннаставне активности, спорт.

РаА је преАат 1. јума 2021. године, а након мишьења рецензената, оАлуком оАговорног уредника Башйине одобрен за штампу. 